\title{
Unregistered Births of Adolescent Mothers in Turkey: Invisible Children
}

\author{
Faruk Keskin, Alanur Çavlin
}

\begin{abstract}
This study examines birth registration for children of adolescent mothers based on family and citizenship concepts, and discusses the negotiation of registration practices between state and family in Turkey. The study is based on two data sources: official Turkish birth statistics from January 2009 to December 2015, and the Turkish Demographic and Health Survey from 2013 (TDHS-2013). We used TDHS-2013 to estimate birth registration completeness and timeliness in Turkey as of 2015. The results show 99 percent completion for birth registration of children under 5 years for the 2011-2015 period. For the same period, 98 percent of births to adolescent mothers were registered, but only 78 percent of all births to adolescent mothers were registered on time - within 30 days. Results indicate that the birth registration system is complete for Turkey in general, even for adolescent mothers, since their offspring are eventually registered, however the timeliness of registration is low for adolescent births. Late registration periods are shortening with time but the rights of unregistered children of adolescent mothers are slow to be recognized in cases where modern regulations of birth registration and traditional family practices collide.
\end{abstract}

Keywords: Turkey · Birth registration · Completeness · Adolescent birth · Citizenship · Family

\section{Introduction}

A child's right to a name and nationality from birth is contained in The Convention on the Rights of the Child (CRC), and birth registration under these guidelines provides the basis for fulfillment of the child's other rights. Article 7 of the CRC establishes that each child "shall be registered immediately after birth and shall have the right from birth to a name, the right to acquire a nationality" (UNICEF 2001). Turkey became a signatory to the CRC in 1990. In the second half of that decade, promoting 
the right of children to birth registration became a major focus of the United Nations Children's Fund (UNICEF) agenda. UNICEF's seminal article, The Progress of Nations (1999), highlighted birth registration as the "first right" upon which access to other rights was dependent, and the article supports UNICEF's current work on birth registration (UNICEF 2013b). The right to birth registration is crucial not only because it is a self-benefitting human right, but also because it enables each child to assert a broad range of other human rights, such as economic, social, cultural, civil and political rights (UNICEF 1999). Vital registration systems can confer citizenship rights and transfer certain characteristic properties to newborns. Furthermore, the Sustainable Development Goals (SDG), the successor of the Millennium Development Goals (MDG), highlight the importance of registration in the new development agenda of the United Nations (UN). Target 16.9 of the SDG is to provide a legal identity for all, including birth registration, by 2030 (UN 2015).

A key component of the vital registration system is birth registration, whereby the state authority first recognizes the existence of a human being. Aggregate data for the population is updated with every entry, thus an effective system of birth registration ensures accurate population data. In theory, the completeness of any registration system is therefore tied to the effective completion of birth registrations. Methods exist to compare birth registrations directly with census data and sample surveys conducted for the particular purpose of calculating completeness; however, some studies use indirect estimation techniques based on inadequate or limited data (Shryock/Siege/ 1976; UNICEF 2005). Birth registration and its level of completeness have been studied by demographers and statisticians primarily as a data quality issue (Mikke/sen et al. 2015). Even when the subject has been examined from a human rights perspective, the relationship between the individual and the state during the registration process has not been discussed separately (Szreter 2007; Todres 2003).

Regardless of modern civil registration methods, considerable portions of the global population are not covered by birth registration systems (Bhatia et al. 2017). The least developed countries share a larger proportion of unregistered births. Several UN and World Health Organization (WHO) reports and publications have addressed the poor state of birth registration in impoverished countries (Setel et al. 2007). In the least developed nations, 45 percent of births are unregistered (UN 2015). Most of the unregistered births are accounted for by developing regions; South Asia and Sub-Saharan Africa together account for 79 percent of all unregistered births (UNICEF 2008). Apart from the importance of birth registration completeness as a statistic, the registration of a birth is a complex bilateral visibility issue encompassing state regulations and parental influence.

\section{Previous research}

Birth registration, identification, and citizenship status are inextricably linked. In the contemporary literature, the effect of citizenship status on migrants' ability to access basic rights and services is widely discussed (Baban et al. 2017; Isin/Nyers 
2014; Shachar 2014; Turner 2016). The circumstances and the fragile situation of children within such migrant populations are highlighted. Research confirms the relative disadvantages of noncitizen populations (mainly unregistered children) with regard to poverty (De Trinidad Young et al. 2018), school enrollment (Patler 2018), and health care access (Oropesa et al. 2016). Children, especially girls, are at the lowest social level in patriarchal family systems. They are considered dependents and not full individuals; therefore, their individual manifestation is not completely acknowledged in many countries. For instance, Li et al. (2010) refer to a father-focused family dynamic as one of the key factors in the low levels of birth registration in China.

Awareness of the importance of birth registration and its completeness grew both internationally and in Turkey in the 1990s. In 1997, the "Working Group Report on Birth and Death Registration in Turkey" was published by the State Statistical Institute (SSI). The report found that birth registration completeness was around 40 percent in 1984, and that the total number of births was estimated by comparing distributed identity cards with census results (State Statistical Institution 1997). This was the first attempt to investigate the completeness of the registration system in Turkey. The timeliness and completeness of the birth registration system have improved over the last decade in Turkey, but there have been no studies on completeness since the last full census in Turkey was held in 2000.

Starting with the 1993 Turkish Demographic and Health Survey (TDHS), the survey results of 1993, 1998, 2003, 2008 and 2013 provided statistics on the completeness of birth registration of children under 5 through information collected from the mother. TDHS results show that the birth registration rate of children under 5 in Turkey was 74 percent in 1993, increasing to 94 percent in 2008 (Hacettepe University Institute of Population Studies 1994, 2014). This period, from the 1990s to 2008, was the most progressive period for the registration system. Koç's work (2004) showed registration completeness levels were lower amongst children with less-educated mothers, as well as among those with mothers whose mother tongue was Kurdish, those who were living in poor households and those whose parents were in religious marriages only. Koç and Eryurt's work (2010) was based on TDHS-2008 and showed that the percentage of unregistered children had decreased radically compared to previous years. According to their study, only 6 percent of children under 5 years of age were unregistered as of 2008. Hoşgör's (2008) study applied feminist methodology to investigate the identity card and citizenship issues, and found that women and girls were the main groups to experience problems related to a lack of birth registration. Recent improvements have led to fewer births now being excluded from the registration system. However, in the last decade, access to civil services has increased for excluded individuals, as all civil rights have been linked to registration (Çavlin Bozbeyoğlu 2011; Çavlin Bozbeyoğlu/Rittersberger Tiliç 2011). More recently, another study (Keskin 2016) showed that the majority of unregistered births in Turkey originates from deceased infants and the children of adolescent mothers. The sex of the child does not affect its registration status.

This study attempts to understand the birth registration patterns for children of adolescent mothers in Turkey in terms of family and citizenship concepts, and 
to understand the practical negotiations that take place between state and family. It will also fill the gap in the literature on the completeness of the birth registration system in Turkey and provide up-to-date results on registration completeness and timeliness by directly analyzing birth registration information with a special focus on the age of the mothers. The study will contribute to the assessment of the completeness and timeliness of birth registration information as of 2015 by analyzing administrative registration data and data from TDHS-2013.

\section{$3 \quad$ Settings}

In Turkey, an exclusively religious marriage is not legally binding; however, the act of dual marriage - religious marriage accompanying a civil one - is the most common type of family formation. Ninety-four percent of all married women (age 15-49) in Turkey have both civil and religious marriage ceremonies (Hacettepe University Institute of Population Studies 2014). The legal age for civil marriage in Turkey is 18, but it is possible to marry at 17 years of age with the permission of the family. Moreover, the courts have the right to approve marriage at age 16 under specific conditions. Consequently, a civil marriage before the age of 18 is not a regular legal act, but an extraordinary event that requires justification in the form of familial and formal approval. In order to prevent child marriage, the Turkish juridical system prohibits religious before civil marriages, yet a significant proportion of couples start their married life with a religious ceremony. According to TDHS-2013, 53 percent of dual-ceremony marriages started with a religious ceremony (Hacettepe University Institute of Population Studies 2014). In practice, early marriages commonly start with a religious ceremony and are legalized with civil marriage when both spouses come of age (Yüksel-Kaptanoğ/u/Ergöģmen 2014). TDHS-2013 results also show that only 18 percent of 15-19-year-old married women use modern contraceptives, so early motherhood is one of the likeliest consequences of adolescent marriage - a fact compounded by the various health risks such as maternal and infant mortality and morbidity, pre-term births and abortion associated with early pregnancies (Chinyere Anozie et al. 2018; Dethloff 2018; Raj 2010; Yüksel-Kaptanoğlu/Ergöçmen 2014).

When the parents have had a civil marriage ceremony, it is sufficient for one of the spouses to apply for birth registration (Law No: 5490 Article:15). If the parents are not married to someone else, or if they are over the age of 18 , the birth registration process is unproblematic for out-of-wedlock parents. However, the registration of a child to an underage mother may trigger criminal proceedings. For this reason, underage couples who have only had a religious marriage may avoid registering their child until the mother's $18^{\text {th }}$ birthday, at which time they usually report a fabricated date of birth. Under these circumstances, there are no delays in the official birth registration statistics, yet the problem of age misreporting remains. Thus, the actual figure of adolescent mothers is quite possibly higher than the estimated value. 
In Turkey, citizenship is mainly defined based on the leges sanguinis principle the law of blood. According to the constitution, Turkish citizenship can be obtained at birth or later in life. Everyone born to parents with Turkish citizenship automatically becomes a citizen of Turkey, and citizens are obliged to register themselves (Turkish Civil Registration Services Law). It is also mandatory for every child to be identified to the population director within thirty days of birth. Upon learning about the existence of unregistered children, the civil registration offices are authorized to invite the parents to make a declaration. However, administrative fines are not imposed on those who did not register at birth within the specified time with the amendment made in the relevant population law in 2017. The process of gaining legal citizenship is thus entrusted to the families of these children. Yeğen (2004) defines Turkish citizenship as passive, republican, and as influencing the private sphere, as opposed to active, liberal or public-oriented. Indeed, although the label of citizen is created upon registration, the emphasis has been on duties rather than rights, and citizenship is considered to be a social practice rather than a mark of social status (Keyman/içduygu 2003). It is incumbent upon the citizen to overcome the obstacles in the way of becoming a registered citizen. This "pacifies" the individual by giving him/her a function within the process. As Keyman and içduygu (2003) argued, this creates a picture of a militant/virtuous form of citizenship in which duties come first and rights can be postponed until these duties have been performed. The state ultimately holds the family responsible for constructing the individual side of the citizenship relationship. Sirman (2005) discusses the gendered citizenship discourse and describes the prevalent form of citizenship in Turkey as "familial citizenship". This discourse is even more powerful in the case of children's citizenship. Families are responsible for registering their newborn as a citizen, and it is their role to establish the first contact between the citizen and the state.

The general understanding of the concept of "family" in Turkish society is no different to its definition in the constitution: Law No. 41 states that family is the foundation of Turkish society and the state shall take the necessary measures and establish the necessary systems to protect the peace and welfare of the family, especially for mothers and children. As emphasized in the law, marriage is the legal basis of family, and forming a family is a common practice in Turkey. The median age of marriage for women 25-49 in Turkey is 21, according to TDHS-2013. The crude marriage rate in Turkey is 7.1 per thousand as of 2017 (TURKSTAT 2018a). According to TDHS-2013, 68 percent of women aged 15-49 are currently married and 2.5 percent of married women only had a religious ceremony. Early marriage is not common practice in Turkey, but it is still a notable factor, with some 89,852 women aged $16-19$ and 9,867 men aged 16-19 marrying in 2017, according to civil registration results for first marriages (TURKSTAT 2018b). While only 2 percent of women in the 15-17 age group are currently married, all of them had religious marriage ceremonies (Hacettepe University Institute of Population Studies 2014). The majority of families are nuclear in Turkey. The extended family has been shrinking rapidly over the last 20 years, and dissolved families are increasing (Koç et al. 2015). 


\section{Layers of Legalization: Citizenship, Family and Registration}

UNICEF (2013a: 11) has argued that: "birth registration may signify the beginning of the legal contract between the individual and the state known as citizenship (...). While birth registration does not itself confer citizenship upon the child, it is often essential for its acquisition based on each country's law." In that respect, this contract and the relationship that starts with birth registration can be perceived and defined differently by the state and the individuals concerned. This relationship, which may be defined as a type of bond, can engender a sense of personal pride, one that arises from being a member of a specific nationality, or from the close connections and feelings toward both individuals and groups within a state, in some cases with the state even being denoted as "father". By contrast, the state's relationship with its people is more rational. The state has several layers of manifestation, some of which are well-known, conventional institutions like the education system, marriage, military service, motherhood, religion, and labor. Each of these layers takes on different characteristics and an image of the person arises from the state's interpretation of these layers. In the end, every individual conveys to the state a different image for each layer of information, and the collection, intersection or combination of these images results in a conclusive relationship between the individual and the state. Based on these perceptions, the state can interpret men, women, the young and old in different ways, and collectively denote any individual or group of people as it pleases, such as mother, student, divorced or retired. While some of these layers are extensively acknowledged, like the sex or religious layers, others are less well recognized, like spending habits or professions. In addition, overlying these layers of human interpretation is a blanket filter that completes the framework; namely, citizenship. These different ways of understanding the individual function best on those with citizenship, a condition defined by the state.

The concept of citizenship is often defined through the rights and obligations of the individual. Authority over rights and regulations of citizenship, and the type of state that wields those powers, defines the type of citizenship. In this sense, liberal, corporatist and social democratic states all interpret citizenship differently (/sin/Turner 2002). While liberal states empower the free market, social-democratic states distribute rights and control obligations through their institutions. Marshall, in his seminal essay, examined citizenship within three dimensions; civil, political and social (Marshall/Bottomore 1950). The civil element is composed of the rights of freedom and the political component is associated with participation, while the social factors include rights that minimize poverty and inequality. The rights and obligations constructed within a family become more apparent during adolescence (Demo 1992). A sense of citizenship is constructed related to these rights and obligations through the process of socialization. This takes place within the family mainly by traditions and everyday social practice (Bier 2010; Galston 1993). This experience of family in childhood determines the individual's behavior later and shapes other rights and obligations. 


\section{$5 \quad$ Data and methods}

The two data sources used for the study are the official birth statistics from January 2009 to December 2015, combined and disseminated by the Turkish Statistical Institute (TURKSTAT), and Turkey Demographic and Health Survey 2013 (TDHS-2013) for individual women's data. ${ }^{1}$ The birth statistics are compiled from two data sources: first the Central Civil Registration System (CCRS), administered by the General Directorate of Population and Citizenship Affairs which covers registered births; and second the Death Notification System (DNS), governed by the Ministry of Health. The latter records infant deaths not previously registered as a live birth. The registered births from CCRS and captured unregistered births from DNS are combined by TURKSTAT to form overall birth statistics. Birth registration data is available in CCRS, starting from 2001 when the system was first established. However, since we used TDHS-2013 data to estimate the completeness of birth registration of children under age 5, analyses of this study are concentrated between the years 2009 and 2015.

The Turkey Demographic and Health Survey 2013, from which the birth registration information is gathered, is a nationally representative sample survey designed to provide information trends on fertility, infant mortality, family planning, and mother and child health. TDHS-2013 was conducted in 81 provinces and 641 clusters. The target sample size of the TDHS-2013 was 14,496 households, with a 93 percent response rate for households and a 90 percent response rate for wom$\mathrm{en}^{2}$ (Hacettepe University Institute of Population Studies 2014). For the TDHS-2013, the field study took place in September 2013-January 2014, and interviews were undertaken with 11,794 households and 9,746 women in the 15-49 age group. The registration status data in TDHS-2013 is collected directly from the mothers of children born in 2003 and later. In the Pregnancy and Fertility section of TDHS-2013, the questions of "Is (child's name) recorded in the population registry?" and "How much time elapsed between (child's name)'s birth and registration?" were asked of women who have had a live birth since January 2003 , including both surviving and deceased children. In TDHS-2013, the registration information was based on the declaration of the mother, as women were not asked to produce birth certificates or an identity card for their children. Concerning the collection of data about the registration date of their children, women may have difficulty in remembering the exact month or year interval in which their children were registered. This could produce a bias, especially for older women and former births. This bias is avoided by collecting data for recent births; specifically, 3,326 children under 5 years of age. ${ }^{3}$ The

1 This study has applied the ethical principles of the Turkish Statistical Institute, which is why aggregate rather than individual data tables from the registration system are employed to maintain privacy. Furthermore, TDHS-2013 has ethical approval from Hacettepe University Academic Ethics Board.

2 For more information on survey design, sampling errors and data quality of TDHS-2013 see Appendix B, C and D of TDHS-2013 main report.

3 Only 8 cases had missing registration dates. 
TDHS sampling frame was chosen from the national registration system, namely the Address Based Population Registration System (ABPRS) and those households not covered by the ABPRS can remain unreported in TDHS (Çavlin Bozbeyoğlu) Rittersberger Tiliç 2011). Although the TDHS listing operation minimized coverage problems, the estimations represented here could not provide information on the coverage of the registration system but they do approximate completeness and timeliness within a period. However, the percentages not registered in the last ten years based on three DHS results are coherent: these are respectively 6.3 percent in TDHS-2008, 1.2 percent in TDHS-2013 and 2 percent in TDHS-2018.

The nature of the birth registration data permits simultaneous calculation of the completeness and timeliness of the registration system, since the backbone of the birth registration information consists of the time interval between the date of birth and the date of birth registration. The time interval between these two events will be referred to as the registration interval. Two separate cross tables of birth registration data were used for the analysis. The first one is the total number of births sorted by the month of birth for each year on the $x$-axis, and month of registration on the $y$-axis. Birth registrations were available from January 2009 until February 2016 for up to 84 months of birth cohorts. Assigning an index to every month starting with January 2009 , this yields an $84 \times 86$ matrix where the entry in the $i$-th row and $j$-th column $\left(\mathrm{a}_{\mathrm{i}, \mathrm{j}}\right.$ where $\left.j>i\right)$ is the number of births registered in month $j$ which are born in month $i$. Since registration cannot happen before birth, all entries where $i>j$ are zero (Equation 1). For example, entry $a_{2,13}$ refers to the February 2009 births registered in January 2010.

$$
\mathrm{A}=\left[\begin{array}{ccccc}
a_{1,1} & \cdots & a_{1,84} & a_{1,85} & a_{1,86} \\
\vdots & \ddots & \vdots & \vdots & \vdots \\
0 & \cdots & a_{84,84} & a_{84,85} & a_{84,86}
\end{array}\right]
$$

The second table is the total number of births sorted by the registration interval categories for each separate year. The registration interval consisted of four categories. The first category are "timely registered" births, referring to births registered in the first 30 days after birth in accordance with the law. The second category refers to "early late registered" births, meaning births registered between 31 days to 90 days postpartum. The third category are "late registered" births, which refers to births registered between 91 days and 1 year postpartum. Finally, the fourth category are "very late registered" births, which refers to births registered after 1 year postpartum, but before the child's $5^{\text {th }}$ birthday.

The analysis of the registration interval was carried out in three steps. The first step was projecting the late registration numbers for rows with less than 60 months of registration information in matrix $A$ for up to 60 months from birth. In order to do so, late registration is modeled with logarithmic regression functions using existing data. Since we already had three months of information for every row, late registration is projected starting from the $4^{\text {th }}$ month after birth. The late registration to timely registration ratios $\left(b_{i, n}\right)$ were calculated for every late registration month between 4 and 60 (Equation 2). 


$$
b_{i, n}=\frac{a_{i, i+n}}{a_{i, i}} \text { for } i=1,2,3, \ldots \text { where } n \in\{3,4, \ldots, 59\}
$$

Using $\left(b_{i, n}\right)$ sequences, logarithmic regression functions are calculated. For example, for the $5^{\text {th }}$ month of registration, $\left(b_{i, 4}\right)$ sequence consisted of 82 values $\left(\frac{a_{1,5}}{a_{1,1},} a_{2,6}, \frac{a_{3,2},}{a_{3,3},} a_{4,4}, \ldots, \frac{a_{2,286}}{a_{82,2}}\right)$. The logarithmic regression function is calculated using these 82 values as input. The regression function is then used to calculate $\frac{a_{83,87}}{a_{83,83}}$ and $\frac{a_{84,88}}{a_{84,84}}$ ratios, thus $\mathrm{a}_{83,87}$ and $\mathrm{a}_{84,88}$ values, since $\mathrm{a}_{83,83}$ and $\mathrm{a}_{84,84}$ values are present in the data. We projected future registration numbers with the help of 57 regression functions, one for every late registration month.

The second step was combining the results of projection and birth statistics for comparison and matching those results to the TDHS birth registration results. To make this comparison, unregistered births were handled in three components. The first component of unregistered births consists of calculated late registrations from the regression function above. This number covers the currently unregistered births that will be registered by their $5^{\text {th }}$ birthday. The second component consists of unregistered births captured by TURKSTAT from the DNS. Among 2009 and 2013 DNS figures, the year 2011 was deficient, so the number of unregistered births captured by DNS for 2011 is interpolated in order to keep a steady trend. The last component, unregistered births that remain unregistered for longer than 5 years postpartum, was calculated from TDHS birth registration results. Births between 2009 and 2013 were selected in the TDHS data and compared with submatrix A where $i \leq 60$ and $j \leq 60$. The total unregistered birth percentage in the selected TDHS data is used to estimate the total number of unregistered births between 2009 and 2013. The first two components are subtracted from this total estimate, and the remaining number becomes the estimated unregistered births that will remain unregistered longer than 5 years postpartum. The total number of unregistered births of the last component was distributed to each year between 2009 and 2013 using the percentage distribution of the second component of unregistered births to the same years. Then, the percentage distribution of the second component was used to calculate the 2014 and 2015 values of the third component.

The last step was preparing a full birth enumeration table to cover both registered and unregistered births, including their completeness and timeliness. With all groups either rearranged, calculated or estimated, the timely registration, late registration and unregistered birth figures are calculated. These estimates are presented for all births and births with adolescent mothers between 2009 and 2015 for each year.

\section{Results}

Table 1 contains information for birth statistics according to the age of the mother between 2009 and 2015, as of February 2016. The number of births of adolescent mothers has fallen by nearly half in 7 years. Despite the reduction, these statistics 
include 18,033 births by mothers younger than 18 years old, making up 14 per thousand of all births in 2015, while this ratio was 26 per thousand with 32,556 births in 2009. Note that the registration information is updated every year for the preceding 5 years. For this reason, the numbers in the table indicate the known births in Turkey as of February 2016, and the registration data for recent years will continue to be updated. Births to mothers of unknown age are also a challenge for the registration system. In the birth registration database, each individual birth matches up with the mother's registration information, including age, based on the identification number. In other words, unless the mother of an individual is unknown, there should be a defined age in all cases. However, the age may be missing in the system in the case of births to foreign mothers. In addition to births to unknown and foreign mothers, some births are accounted for by women who are outside the reproductive age limits, i.e. they are either too young or too old. In these cases, women are possibly mismatched with the data, or the age of the women is wrong. These unknown cases are excluded from the analysis.

Tab. 1: Birth statistics of Turkey by age of mother, 2009-2015

\begin{tabular}{lcccccccr}
\hline & \multicolumn{8}{c}{ Age of mother } \\
Year of & \multicolumn{1}{c}{$<$} & \multicolumn{2}{c}{$18+$} & \multicolumn{2}{c}{ Unknown } & \multicolumn{2}{c}{ Total } \\
birth & Number & Percent & Number & Percent & Number & Percent & Number & Percent \\
\hline 2009 & 32,556 & 2.6 & $1,225,759$ & 96.8 & 8,436 & 0.7 & $1,266,751$ & 100.0 \\
2010 & 30,165 & 2.4 & $1,222,165$ & 96.9 & 8,839 & 0.7 & $1,261,169$ & 100.0 \\
2011 & 26,804 & 2.1 & $1,212,126$ & 97.1 & 9,620 & 0.8 & $1,248,550$ & 100.0 \\
2012 & 24,516 & 1.9 & $1,256,682$ & 97.2 & 11,182 & 0.9 & $1,292,380$ & 100.0 \\
2013 & 22,181 & 1.7 & $1,259,665$ & 97.3 & 12,242 & 0.9 & $1,294,088$ & 100.0 \\
2014 & 20,599 & 1.5 & $1,313,617$ & 97.6 & 11,070 & 0.8 & $1,345,286$ & 100.0 \\
2015 & 18,033 & 1.4 & $1,297,312$ & 97.9 & 10,438 & 0.8 & $1,325,783$ & 100.0 \\
\hline
\end{tabular}

Source: Turkstat birth statistics data

Table 2 shows the birth statistics of mothers under 18 years old. Since the system is updated for the 5 years prior to each year, the numbers are almost complete for the first few years, while the very late registration period is missing for recent years. More specifically, late registration and very late registration of birth cohort 2015 and very late registration of birth cohort 2016 are still censored. Regardless, the decrease in timely registrations is an important sign of a reduction in the number of adolescent births. Here, the number of unregistered births refers to infant deaths of adolescent mothers captured by the Death Notification System.

Table 3 shows the total estimated births including the late registration projections from the birth statistics and the unregistered proportion estimation from TDHS-2013. Model estimates of late registration confirm the decrease in total births to adolescent mothers between 2009 and 2015. Moreover, results also show that the timeliness of the registration has also improved over the years. In this stage of the analysis, we introduced the number of births estimated to remain unregistered for at least 5 years after birth. If we focus on the most recent estimates, the model 
Tab. 2: Birth statistics of adolescent mothers in Turkey, 2009-2015

\begin{tabular}{lccccrc}
\hline $\begin{array}{l}\text { Year of } \\
\text { birth }\end{array}$ & $\begin{array}{c}\text { Timely } \\
\text { registered } \\
\text { (0-30 days) }\end{array}$ & $\begin{array}{c}\text { Early late } \\
\text { registered } \\
(31-90 \text { days })\end{array}$ & $\begin{array}{c}\text { Late } \\
\text { registered } \\
\text { (91-365 days) }\end{array}$ & $\begin{array}{c}\text { Very late } \\
\text { registered } \\
(>1 \text { year })\end{array}$ & $\begin{array}{c}\text { Unregistered } \\
\text { infant deaths }\end{array}$ & $\begin{array}{c}\text { Total } \\
\text { births }\end{array}$ \\
\hline 2009 & 19,111 & 2,127 & 4,654 & 6,506 & 158 & 32,556 \\
2010 & 20,337 & 1,792 & 3,832 & 4,082 & 122 & 30,165 \\
2011 & 19,572 & 1,845 & 2,877 & 2,510 & $*$ & 26,804 \\
2012 & 18,880 & 1,792 & 2,177 & 1,585 & 82 & 24,516 \\
2013 & 17,951 & 1,516 & 1,684 & 943 & 87 & 22,181 \\
2014 & 17,048 & 1,571 & 1,447 & 451 & 82 & 20,599 \\
2015 & 15,782 & 1,391 & 789 & 14 & 57 & 18,033 \\
\hline
\end{tabular}

* Data of unregistered infant deaths are not available for the year 2011

Source: Turkstat birth statistics data

estimates for the year 2015 show that an additional 11 births in the early late registration period, 400 births in the late registration period, and 382 births in the very late period will be registered. In addition to these late registration cases, 57 births are not registered at all and 21 births remain unregistered at the time of their $5^{\text {th }}$ birthday.

Tab. 3: Estimation of adolescent births in Turkey, 2009-2015

\begin{tabular}{lccccccc}
\hline & $\begin{array}{c}\text { Timely } \\
\text { Year of } \\
\text { registered } \\
\text { (0-30 days) }\end{array}$ & $\begin{array}{c}\text { Early late } \\
\text { registered } \\
\text { (31-90 days) }\end{array}$ & $\begin{array}{c}\text { Late } \\
\text { registered } \\
(91-365 \text { days })\end{array}$ & $\begin{array}{c}\text { Very late } \\
\text { registered } \\
(>1 \text { year })\end{array}$ & $\begin{array}{c}\text { Unregistered } \\
\text { infant deaths }\end{array}$ & $\begin{array}{c}\text { registered at } \\
5^{\text {th }} \text { birthday }\end{array}$ & $\begin{array}{c}\text { Total } \\
\text { births }\end{array}$ \\
\hline 2009 & 19,111 & 2,127 & 4,654 & 6,486 & 158 & 59 & 32,595 \\
2010 & 20,337 & 1,792 & 3,832 & 4,071 & 122 & 45 & 30,199 \\
2011 & 19,572 & 1,845 & 2,877 & 2,520 & 105 & 39 & 26,958 \\
2012 & 18,880 & 1,792 & 2,177 & 1,631 & 82 & 30 & 24,592 \\
2013 & 17,951 & 1,516 & 1,684 & 1,029 & 87 & 32 & 22,299 \\
2014 & 17,048 & 1,571 & 1,447 & 670 & 82 & 30 & 20,848 \\
2015 & 15,782 & 1,404 & 1,189 & 396 & 57 & 21 & 18,849 \\
\hline
\end{tabular}

Source: Own calculation based on birth statistics and TDHS-2013

In the next stage, we limit our analysis to under-5s based on records as of Dec. 31, 2015 (Table 4). According to this framework, some of the very late registered births in all 5 calendar years and some births in each registration status category are calculated and redistributed. Consequently, we take a snapshot of the birth registration completeness and timeliness for a 5-year period at the end of 2015. Since the cutoff point was selected as Dec. 31, 2015, births registered after that date and projected births with date of registration later than that are taken as unregistered. Accordingly, Table 4 presents the number of unregistered births in two categories 
190 - Faruk Keskin, Alanur Çavlin

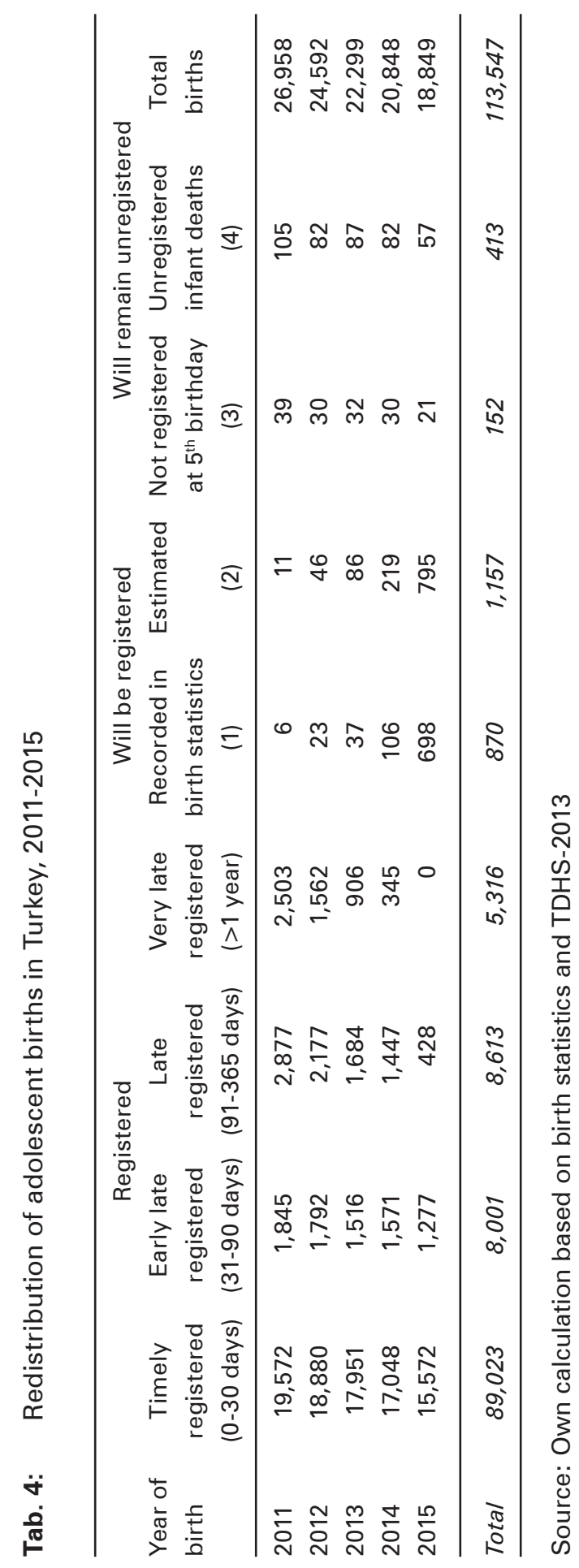


and four different sub-categories: for births that will be registered after the cut-off point, (1) those that are recorded in birth statistics, and (2) estimated births that will be registered. Then, for births that will remain unregistered, we show (3) estimated unregistered births at $5^{\text {th }}$ birthday, and (4) unregistered infant deaths.

Table 5 presents the final stage of the analysis for the total births as well as adolescent births. According to the results of the calculation, 99 percent of all births between 2011 and 2015 had been registered by the end of 2015 (Table 5). In other words, the birth registration system for children under 5 years is 99 percent complete as of 2015. Of all births, 95 percent were registered in a timely fashion, within 30 days following the birth, and 4 percent of births were registered late. The results show that only 1 percent of all births $(69,141)$ between 2011 and 2015 were unregistered at the end of 2015. Projections estimated that more than half (57 percent) of the currently unregistered children will be registered before their 5th birthday, but they will still be counted as late registers. Calculations show that almost 1 out of 3 (31 percent) unregistered births were infant deaths captured by DNS. Both unregistered births of deceased infants captured via DNS and the percentage of unregistered births of deceased children in TDHS-2013 data indicate that there is a considerable number of unregistered cases in this group. Although we have the quantity information about the vast majority of children in this group, they are not registered in the civil registration system. The remaining 12 percent of unregistered births will be unregistered, even 5 years following their birth. In total, 4.5 per 1,000 births between 2011 and 2015 will still be unregistered by the child's $5^{\text {th }}$ birthday.

Tab. 5: Estimation of completeness and timeliness of the birth registration system in Turkey, 2011-2015

\begin{tabular}{lrrrr}
\hline Registration status & $\begin{array}{c}\text { Adolescent births (under 18) } \\
\text { registration }\end{array}$ & \multicolumn{2}{c}{$\begin{array}{c}\text { Total birth } \\
\text { registration }\end{array}$} \\
& Number & Percentage & Number & Percentage \\
\hline Registered births & 110,954 & 97.72 & $6,470,042$ & 98.94 \\
Timely & 89,023 & 78.40 & $6,239,585$ & 95.42 \\
$\quad$ Early late (31-90 days) & 8,001 & 7.05 & 137,334 & 2.10 \\
Late (91-365 days) & 8,613 & 7,58 & 64,025 & 0.98 \\
Very late (More than 1 year) & 5,316 & 4.68 & 29,098 & 0.44 \\
Total late registration & 21,931 & 19.31 & 230,457 & 3.52 \\
\hline Unregistered births & 2,593 & 2.28 & 69,141 & 1.06 \\
$\quad$ Remain unregistered & 566 & 0.49 & 29,694 & 0.45 \\
Will be registered & 2,027 & 1.79 & 39,448 & 0.60 \\
Total & 113,547 & 100.00 & $6,539,183$ & 100.00 \\
\hline
\end{tabular}

Source: Own calculation based on birth statistics and TDHS-2013

While completeness and timeliness of registration are promising for all births, the picture is slightly different for births to adolescent mothers. The results show that 98 percent of births to adolescent mothers between 2011 and 2015 were reg- 
istered by the end of 2015. Completeness of registration seems high for children of adolescent mothers, however only 78 percent of all births to adolescent mothers were registered on time. Some 19 percent of these births were registered late. In addition, almost 10 percent of late-registered children have adolescent mothers. Estimated results show that 2 percent of adolescent births $(2,593)$ between 2011 and 2015 were unregistered at the end of 2015 . While most of the unregistered births to adolescent mothers $(2,027)$ are expected to be registered within a year, 22 percent (566) will remain unregistered. The number of children of adolescent mothers who will remain unregistered until their $5^{\text {th }}$ birthday is lower than the total unregistered births, but that percentage is still elevated. The completeness of this group also seems high, but timeliness was conspicuously low compared to the registration of all births. Together, the percentage of timely registration and the portion of births remaining unregistered indicate resistance to registration in the case of adolescent mothers.

In addition to the 5-year registration data, we can also construct the births of the 2009-2015 period with birth cohorts according to birth registration groups. Figure 1 represents the percentages of births in Turkey between 2009 and 2015, with estimates of unregistered births and late registrations that are calculated for 5 years following the birth year (early, late and very late registration). As expected, the majority of births are registered in time, as legally specified. Improvements in completeness and timeliness are readily apparent, since the total of late registrations and unregistered births account for more than 10 percent of births in 2009, dropping to under 4 percent in 2015. The improvement for adolescent mothers was even more remarkable, with late registrations falling from 40 percent to 16 percent over 7 years. The late registrations that occurred between 31 days and 5 years seem to decrease over time for both adolescent mothers and total births. The registration interval was significantly shortened; each group of late registrations improved, with the exception of the early late registration group of adolescent mothers' births. The decrease in late registration for Turkey mostly originated from this early late registration group: those who registered between 31-90 days. In 2009, 4.9 percent of the births were in this group, declining to 1.6 percent in 2015. This improvement in early late registered births implies an improvement in timeliness in the registration system. Although the number of adolescent births has significantly decreased, the early late registration group was slow to follow this trend. In fact, the percentage of births that fell into the early late registration group increased from 2009 to 2015 . The timely registration group increased, there were visible improvements in very late registrations and the early late registration group grew, meaning that there was a shift in the late registration groups toward shorter intervals of late registration. The total of late registration and unregistered births was above 40 percent and nearly half were the very late registrations in 2009, falling to 16 percent in 2015. This shift is a signal of the dissolution of resistance.

Mirroring the improvements in the registration system, timely registration increased from 89.3 percent in 2009 to 96.9 percent in 2015. The increases were sharper in the early years but slowed as the system improved. Timely registration of adolescent mothers' births rose from 58.6 percent to 83.7 percent in 7 years. 
Fig. 1: Estimation of timely registration, distribution of late registration and unregistered births in Turkey, 2009-2015*

Late registration

Timely registration

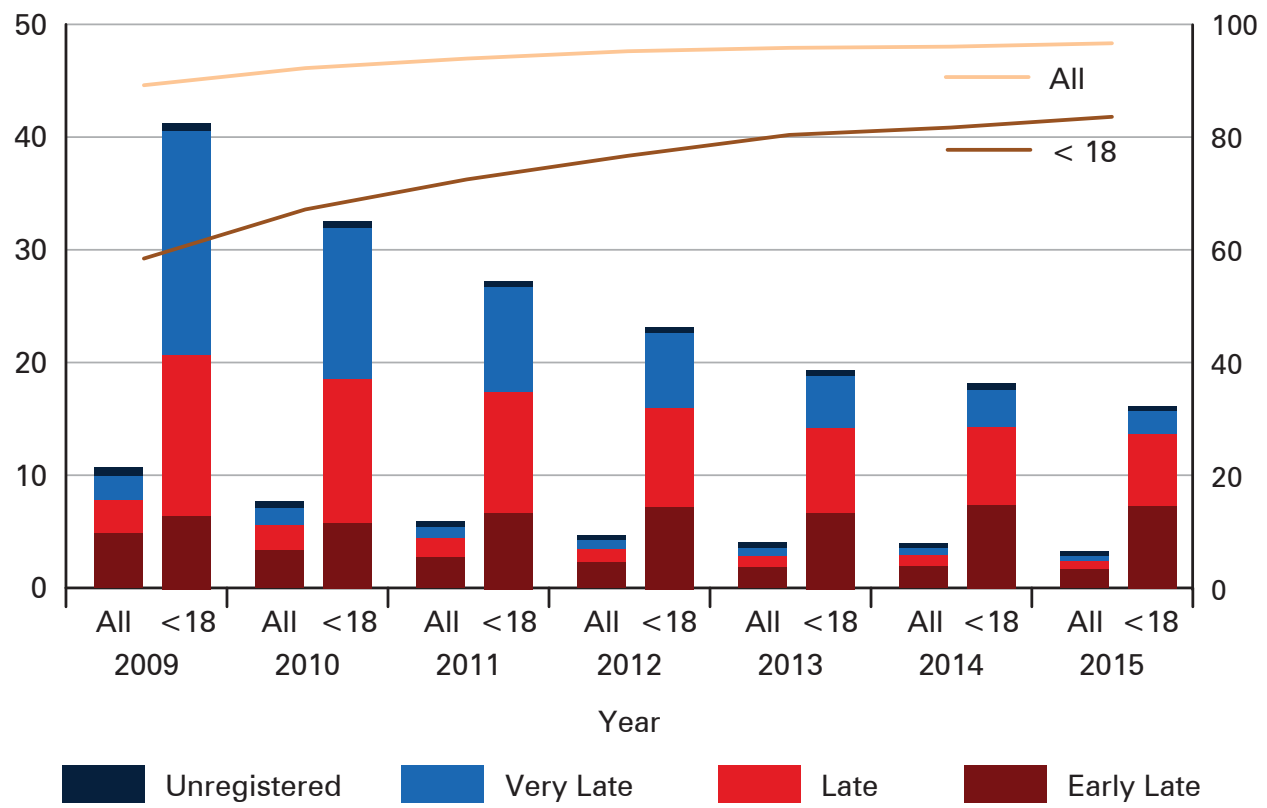

* Line graphs show registered births and bar graphs show late registrations and unregistered births.

Source: Own calculation based on birth statistics and TDHS-2013

Although the increase over such a short period is noteworthy, it is still very far from the timeliness of total birth registration.

\section{Conclusion}

Besides having human rights, children also have extended rights which derive from certain international documents. International laws aim to protect every person, particularly every child, and states are legally responsible for upholding these special provisions (UNICEF 2001). However, this protective shield is only available when the children concerned are visible to the state. Without the relevant information about each child, the state cannot provide the customary protections. In order to be seen by the state, a child must be registered at birth and the family has a primary duty of initiating the citizenship process through timely birth registration. Unfortunately, the fulfillment of these parental responsibilities suffers when the parents are children themselves. The unregistered child of an adolescent mother does not enjoy 
full rights, even if the mother is an acknowledged citizen. Without official status, a child is effectively nonexistent, legally invisible in the eyes of the state.

The Centennial Registration System in Turkey is a good example of a recently improved registration system. Birth registration details are now becoming available and can serve as the basis for studying completeness and timeliness. This study estimates birth registration completeness and timeliness in Turkey with a special focus on births to adolescent mothers. This is the very first attempt to evaluate the civil registration and vital statistics system itself by using the 2013 Turkey Demographic and Health Survey and the Turkey National Death Notification System as secondary data sources. The method we use in this study allows us to comment on the completeness and timeliness of the registration system with the help of secondary sources. The main results underline the disadvantages of adolescent birth, in spite of a general advancement in birth registration. The results show that Turkey had 99 percent under-5 birth registration completeness for the 2011-2015 period, and 95 percent of all births were registered in time. Estimates show that 1 percent of births were unregistered and 0.05 percent of all births will remain unregistered for 5 years. The calculations for adolescent mothers showed that birth registration completeness was slightly lower than the results for all of Turkey, with 98 percent of all births to adolescent mothers being registered. However, the difference in timeliness was significant, with the level of timely registration of births to adolescent mothers at 78 percent between 2011 and 2015.

The late registration of adolescent births improved during the period in question, however there was a slight increase in early-late registration. These observations indicate a decrease in the waiting interval until adolescent mothers turn 18 and register their births. In other words, the increase in early late registration rates confirms that adolescent marriages in Turkey occur mostly in the late adolescent age group. Overall, we can state that the birth registration system is complete for Turkey and for adolescent mothers, since the children of adolescent mothers are eventually registered; however, the timeliness of the birth registration is low for adolescent births. Low timeliness causes the children of adolescent mothers to live without identification longer than the children of adults. Those children spend the most fragile period of their lives, biologically speaking, as invisible persons. Since we can only identify the births of adolescents if they are registered before the mother turns 18 , this means the numbers obtained through birth registration underestimate the total births of adolescent mothers. Furthermore, since the reporting of a birth to an adolescent opens a criminal case, adolescent mothers may misreport the child's birth date. This can cause further underestimation. This issue may lead to risks such as inaccurate follow-up of vaccinations and delayed school enrollment. Unfortunately, neither data source included information on births registered with a false date. Thus, the numbers and percentages presented here should be seen as a best-case scenario. In addition, the study is limited by the absence of a census for matching and comparing the administrative birth registration data.

Civil law determines the minimum age of marriage in Turkey; however, social norms and perceptions regarding sexual activity and marriage continue to be strong and stable, as is also observed in the Middle East and North African countries (Pret- 
titore 2015). One of the reasons for this conflict is the cultural strength of the early marriage tradition, despite the changes to civil laws in Turkey with the proclamation of the Republic more than 90 years ago. Women were at the heart of the modernization project of the Republic of Turkey, yet not with regard to their individual rights (Kadıoğlu 1994). Women's rights and regulations were accepted as a national mission or a kind of national symbol in Turkey, but at the same time women were defined within the family as non-individuals. Therefore, the customs regarding family and kinship formation, including marriage, have not evolved. Without a change in the perception of family foundation in society, top-down legislation can only have a limited impact on practices. This shows that the acceptance of marriage by society is still more important than acceptance by the state. Regardless of the differences in their socio-economic status, families in Turkey have traditionally tended to restrict adolescent sexual activity and motivate or force young people into marriage with their very first signs of sexual interest (Yüksel-Kaptanoğlu/Ergöçmen 2014). Sexual activity is directly linked to marriage and also correlated with pregnancy. Married adolescents become strong candidates for having births that are within wedlock from the parents' point of view, but out of wedlock and illegal in the eyes of the state, this multiplies the risks for their children, since they are then kept out of the citizenship framework. Unregistered children in this setting are invisible and, furthermore, the underage mother of the unregistered children does not participate actively in any discourse with the state.

The state defines citizenship as the first duty of a citizen and aims to improve the registration of births, yet the fact that it ignores the unregistered children of more vulnerable groups highlights the disconnect between official regulations and cultural norms. The temporary period during which the children of underage women remain unregistered represents an unspoken agreement, rather than a conflict, between state and family wherein the state turns a blind eye and loosens its age restrictions for marriage, with eventual compliance being assumed. The strong family ideology means that the sanctity of family surpasses both the construct of citizenship and the regulating power of the state. As an indicator of this, it is not the state but the families themselves which are responsible for registering newborns. The agreement between state and family also emphasizes the true nature of citizenship dominant in Turkey in which political and civil concepts are so often eclipsed by the country's strong traditional outlook. Legal immunity based on the sanctity of the family is indeed observed mostly in religious families in cases where marriages take the form of traditional religious ceremonies. While the state rejects this agreement, both verbally and legally, the actual practice and the number of the family formations that occur before the age of 18 are reflected in the contradictory reality.

Strong cultural norms have shaped citizenship in Turkey and its perception. For this reason, the citizenship filter and the layers of the state are constructed upon this traditional cultural foundation and family is kept as the focus of society, not the individual. Following the launch of the Address Based Population Registration System, this conflict became more visible and measurable. The number of unregistered people has decreased due to the increased need to register through integrated electronic systems with ID numbers. However, many have increasingly been 
denied basic civil services since the state began to recognize only those who are registered. Before, unregistered children could receive health care, become vaccinated and even be enrolled in schools. Now, none of these services are available for unregistered children (Koc/Eryurt 2010). The requirement for an ID number in order to access health services is the main reason for the increase in birth registrations in Turkey over the last 20 years. However, there is resistance to such a basic regulation as the registration of birth in traditional or religious circles. Thus, the unregistered births of adolescent mothers do not represent a challenge for the registration system, rather they are related to the ongoing cultural permission of early marriage, despite its official condemnation. Since this is a type of cultural resistance, and the conflict with the law is regarded as a negotiation between the state and family, it is a difficult problem to overcome.

\section{Acknowledgements}

We would like to thank İlknur Yüksel-Kaptanoğlu for her feedback at the early stages of this paper and acknowledge the helpful comments of Tuğba Adalı. Moreover, we thank two anonymous referees for their valuable comments and the language editors of CPoS. This paper is based on the MA thesis of Faruk Keskin, prepared under the supervision of Alanur Çavlin.

\section{References}

Baban, Feyzi; Ilcan, Suzan; Rygiel, Kim 2017: Syrian Refugees in Turkey: Pathways to Precarity, Differential Inclusion, and Negotiated Citizenship Rights. In: Journal of Ethnic and Migration Studies 43,1: 41-57 [doi: 10.1080/1369183X.2016.1192996].

Bhatia, Amiya et al. 2017: Who and Where Are the Uncounted Children? Inequalities in Birth Certificate Coverage among Children under Five Years in 94 Countries Using Nationally Representative Household Surveys. In: International Journal for Equity in Health 16,1: 1-11 [doi: 10.1186/s12939-017-0635-6].

Bier, Laura 2010: The Family Is a Factory: Gender, Citizenship, and the Regulation of Reproduction in Postwar Egypt. In: Feminist Studies 36,2: 404-432.

Çavlin Bozbeyoğlu, Alanur 2011: Citizenship Rights in a Surveillance Society: The Case of the Electronic ID Card in Turkey. In: Surveillance and Society 9,1-2: 6 4-79 [doi: 10.24908/ss.v9i1/2.4095].

Çavlin Bozbeyoğlu, Alanur; Rittersberger Tiliç, Helga 2011: The Relationship between the Changes in the Population Information System and the 'Citizen' Participating in Public Administration and Benefiting from Public Services in Turkey: Transition from de Facto Population Census to Address-Based Registrationation. In: Amme Idaresi Dergisi 44,1: 89-112.

Chinyere Anozie, Miriam; Ele, Millicent; Anika, ljeamaka Elizabeth 2018: The Legal, Medical and Social Implications of Child Marriage in Nigeria. In: International Journal of Law, Policy and the Family 32,2: 119-139 [doi: 10.1093/lawfam/eby002].

Demo, David H. 1992: Parent-Child Relations: Assessing Recent Changes. In: Journal of Marriage and the Family 54,1: 104-117 [doi: 10.2307/353279]. 
Dethloff, Nina 2018: Child Brides on The Move: Legal Responses to Culture Clashes. In: International Journal of Law, Policy and the Family 32,3: 302-315 [doi: 10.1093/lawfam/ eby008].

Galston, William A. 1993: Liberal Purposes: Goods, Virtues, and Diversity in the Liberal State. In: Ethics: An International Journal of Social, Political, and Legal Philosophy 103,2 [doi: 10.1086/293510].

Hacettepe University Institute of Population Studies 1994: 1993 Turkey Demographic and Health Survey. Ankara.

Hacettepe University Institute of Population Studies 2014: 2013 Turkey Demographic and Health Survey. Ankara.

Hoşgör, Ayşe Gündüz 2008: Kadın Vatandaşlık Haklarındaki En Temel Sorun: ‘Nüfus Cüzdanım Yok Ki!'. In: Toplum ve Demokrasi 2,4: 27-38.

Isin, Engin F.; Nyers, Peter 2014: Introduction: Globalizing Citizenship Studies. In: Isin, Engin F.; Nyers, Peter: Routledge Handbook of global citizenship studies. London: Routledge: 23-33.

Isin, Engin F.; Turner, Bryan S. 2002: Handbook of Citizenship Studies. 1st ed. London: SAGE Publications Ltd. [doi: 10.4135/9781848608276].

Kadıoğlu, Ayşe 1994: Women's Subordination in Turkey: Is Islam Really the Villain? In: Middle East Journal 48,4: 645-660.

Keskin, Faruk. 2016: Estimating The Completeness of Birth Registration System in Turkey: Comparison Between MERNIS and Turkey Demographic And Health Survey [Unpublished M.A. Thesis]. Hacettepe University.

Keyman, E. Fuat; içduygu, Ahmet 2003: Globalization, Civil Society and Citizenship in Turkey: Actors, Boundaries and Discourses. In: Citizenship Studies 7,2: 219-234 [doi: 10.1080/1362102032000065982].

Koç, Ismet 2004: Türkiye'de Çocukların Nüfusa Kayıtlı Olmamasını Etkileyen Değişkenler ve Nüfusa Kayıtlı Olmaya Geçiş Süreci. In: Nüfusbilim Dergisi|Turkish Journal of Population Studies 26: 35-44.

Koç, İsmet et al. 2015: Türkiye'de Aile Yapısının Değişimi: 1968-2013. In: 2013 Türkiye Nüfus ve Sağlık Araştırması İleri Analiz Çalışması: 1-47.

Koc, Issmet; Eryurt, Mehmet Ali 2010: Türkiye'de Beş Yaş Altındaki Çocukların Nüfusa Kayıt Olma Durumları: 1993-2008. In: Çocuk Sağlığı ve Hastalıkları Dergisi 53: 114-121.

Li, Shuzhuo; Zhang, Yexia; Feldman, Marcus W. 2010: Birth Registration in China: Practices, Problems and Policies. In: Population Research and Policy Review 29,3: 297-317 [doi: 10.1007/s11113-009-9141-x].

Marshall, Thomas H.; Bottomore, Tom 1950: Citizenship and Social Class. Vol. 11. Cambridge.

Mikkelsen, Lene et al. 2015: A global assessment of civil registration and vital statistics systems: monitoring data quality and progress. In: The Lancet 386(10001): 1395-1406 [doi: 10.1016/S0140-6736(15)60171-4].

Oropesa, Ralph Salvador; Landale, Nancy S.; Hillemeier, Marianne M. 2016: Legal Status and Health Care: Mexican-Origin Children in California, 2001-2014.In: Population Research and Policy Review 35,5: 651-684 [doi: 10.1007/s11113-016-9400-6].

Patler, Caitlin 2018: Citizen Advantage, Undocumented Disadvantage, or Both? The Comparative Educational Outcomes of Second and 1.5-Generation Latino Young Adults. In: International Migration Review 52,4: 1080-1110 [doi: 10.1111/imre.12347]. 
Prettitore, Paul Scott 2015: Family Law Reform, Gender Equality, and Underage Marriage: A View from Morocco and Jordan. In: The Review of Faith \& International Affairs 13,3: 32-40 [doi: 10.1080/15570274.2015.1075758].

Raj, Anita 2010: When the mother is a child: the impact of child marriage on the health and human grights of Girls. In: Archives of Disease in Childhood 95,11: 931-935 [doi: 10.1136/adc.2009.178707].

Setel, Philip W. et al. 2007: A scandal of invisibility: making everyone count by counting everyone. In: Lancet 370,9598: 1569-1577 [doi: 10.1016/S0140-6736(07)61307-5].

Shachar, Ayelet 2014: Introduction: Citizenship and the 'Right to Have Rights'. In: Citizenship Studies 18,2: 114-124 [doi: 10.1080/13621025.2014.886389].

Shryock, Henry S.; Siegel, Jacob S. 1976: Natality: Measures Based on Vital Statistics. In: The Methods and Materials of Demography 52: 273-296 [doi: 10.1016/B978-0-12641150-8.50020-2].

Sirman, Nükhet 2005: The Making of Familial Citizenship in Turkey. In: Citizenship in a Global World: European Questions and Turkish Experiences. London: Routledge: 147-172.

State Statistical Institution 1997: Working Group Report on Birth and Death Registration in Turkey. Ankara.

Szreter, Simon 2007: The Right of Registration: Development, Identity Registration, and Social Security-A Historical Perspective. In: World Development 35,1: 67-86 [doi: 10.1016/j.worlddev.2006.09.004].

Todres, Jonathan 2003: Birth Registration: An Essential First Step toward Ensuring the Rights of All Children. In: Human Rights Brief 10,3: 32-35.

De Trinidad Young, Maria Elena et al. 2018: More Inclusive States, Less Poverty Among Immigrants? An Examination of Poverty, Citizenship Stratification, and State Immigrant Policies. In: Population Research and Policy Review 37,2: 205-228 [doi: 10.1007/ s11113-018-9459-3].

TURKSTAT 2018a: Marriage and Divorce Statistics, 2017 [http://www.turkstat.gov.tr/PreHaberBultenleri.do?id=27593, 20.12.2018].

TURKSTAT 2018b: Spouses by Respective Age Group [http://www.turkstat.gov.tr/PreIstatistikTablo.do?istab_id=80, 20.12.2018].

Turner, Bryan S. 2016: We Are All Denizens Now: On the Erosion of Citizenship. In: Citizenship Studies 20,6-7: 679-692 [doi: 10.1080/13621025.2016.1191432].

UN 2015: The Millennium Development Goals Report. New York: United nations.

UNICEF 1999: The Progress of Nations. New York: UNICEF.

UNICEF 2001: The Convention on the Rights of the Child. In: Health and Human Rights 5,2: 175. New York: UNICEF.

UNICEF 2005: The "Rights" Start to Life: A Statistical Analysis of Birth Registration. New York: UNICEF.

UNICEF 2008: Strengthening Birth Registration in Africa Opportunities and Partnerships. New York: UNICEF.

UNICEF 2013a: A Passport To Protection. New York: UNICEF.

UNICEF 2013b: Every Child's Birth Right: Inequities and Trends in Birth Registration. New York: UNICEF.

Yeğen, Mesut 2004: Citizenship and Ethnicity in Turkey. In: Middle Eastern Studies 40,6: 51-66 [doi: 10.1080/0026320042000282874]. 
Yüksel-Kaptanoğlu, IIknur; Ergöçmen, Banu Akadli 2014: Early Marriage: Trends in Turkey, 1978-2008. In: Journal of Family Issues 35,12: 1707-1724 [doi: $10.1177 / 0192513 \times 14538025]$.

Faruk Keskin ( $\triangle)$, Dr. Alanur Çavlin. Hacettepe University, Institute of Population Studies. Ankara, Turkey.

E-mail: farukkeskin@hacettepe.edu.tr, alanurcv@hacettepe.edu.tr

URL: http://www.hips.hacettepe.edu.tr/eng/kadro/faruk_keskin.pdf https://hacettepe.academia.edu/alanurCavlinBozbeyoglu 


\section{Comparative Population Studies}

WWW.comparativepopulationstudies.de

ISSN: 1869-8980 (Print) - 1869-8999 (Internet)

\section{Published by}

Prof. Dr. Norbert F. Schneider

Federal Institute for Population Research D-65180 Wiesbaden / Germany

\section{(cc) BY-SA}

2020

\section{Managing Editor}

Prof. Dr. Johannes Huinink

Dr. Katrin Schiefer

\section{Editorial Assistant}

Beatriz Feiler-Fuchs

Wiebke Hamann

\section{Layout}

Beatriz Feiler-Fuchs

E-mail:cpos@bib.bund.de

\section{Scientific Advisory Board}

Karsten Hank (Cologne)

Michaela Kreyenfeld (Berlin)

Marc Luy (Vienna)

Natalie Nitsche (Rostock)

Zsolt Spéder (Budapest)

Rainer Wehrhahn (Kiel)

\section{Board of Reviewers}

Bruno Arpino (Barcelona)

Kieron Barclay (Rostock)

Laura Bernardi (Lausanne)

Gabriele Doblhammer (Rostock)

Anette Eva Fasang (Berlin)

Michael Feldhaus (Oldenburg)

Tomas Frejka (Sanibel)

Alexia Fürnkranz-Prskawetz (Vienna)

Birgit Glorius (Chemnitz)

Fanny Janssen (Groningen)

Frank Kalter (Mannheim)

Stefanie Kley (Hamburg)

Bernhard Köppen (Koblenz)

Anne-Kristin Kuhnt (Duisburg)

Hill Kulu (St Andrews)

Nadja Milewski (Rostock)

Roland Rau (Rostock)

Thorsten Schneider (Leipzig)

Tomas Sobotka (Vienna)

Jeroen J. A. Spijker (Barcelona)

Heike Trappe (Rostock)

Helga de Valk (The Hague)

Sergi Vidal (Barcelona)

Michael Wagner (Cologne) 